\title{
Meanings of flower therapy for anxiety in people with overweight or obesity
}

\author{
Significados da terapia floral para ansiedade em pessoas com sobrepeso ou obesidade \\ Significados de la terapia floral para la ansiedad en personas con sobrepeso u obesidad
}

\begin{abstract}
Ana Paula Pancieri', Suzimar Benato Fusco', Bianca Ires Abrantes Ramos', Eliana Mara Braga'
'Universidade Estadual Paulista Júlio de Mesquita Filho, Botucatu Medical School. Botucatu, São Paulo, Brazil.
\end{abstract}

How to cite this article:

Pancieri AP, Fusco SB, Ramos BIA, Braga EM. Meanings of flower therapy for anxiety in people with overweight or obesity. Rev Bras Enferm [Internet]. 2018;71(Suppl 5):2310-5. [Thematic Issue: Mental health] DOI: http://dx.doi.org/10.1590/0034-7167-2018-0044

\author{
Submission: 02-04-2018 Approval: 03-21-2018
}

\section{ABSTRACT}

Objective: To understand the experience from the perspective of the participant of a clinical research, which had as intervention the flower therapy for anxiety of individuals with overweight and obesity. Method: qualitative study, developed by semi-structured interview with 42 participants from a clinical research and data submitted to content analysis. Results: after analysis, five thematic categories emerged: seeking natural alternatives to aid in control of anxiety and obesity; perceiving the benefits of flower therapy in itself and in family and professional relationships; recognizing flower therapy as source of tranquility and self-knowledge; perceiving changes in sleep quality; acquiring self-control and guidance on food and relational needs. Final considerations: the participants showed the intention of seeking natural alternatives to aid the control of anxiety and obesity, employing complementary therapies to strengthen their health. Consequently, participants reported self-control in feeding and in family and professional relationships. Descriptors: Flower Essences; Clinical Trial; Qualitative Research; Anxiety; Obesity.

\section{RESUMO}

Objetivo: Compreender a experiência sob a perspectiva do participante de uma pesquisa clínica, que teve como intervenção a terapia floral para ansiedade de indivíduos com sobrepeso e obesidade. Método: estudo qualitativo, desenvolvido por entrevista semiestruturada com 42 participantes de uma pesquisa clínica e dados submetidos à análise de conteúdo. Resultados: após análise, emergiram cinco categorias temáticas: Buscando alternativas naturais para auxiliar no controle da ansiedade e obesidade; Percebendo os benefícios da terapia floral em si mesmo e em pessoas das relações familiares e profissionais; Reconhecendo a terapia floral como fonte de tranquilidade e autoconhecimento; Percebendo mudanças na qualidade do sono; Adquirindo autocontrole e direcionamento nas necessidades alimentares e relacionais. Considerações finais: os participantes revelam a intenção de buscar alternativas naturais para auxiliar o controle da ansiedade e obesidade, apropriando-se de terapias complementares para fortalecer sua saúde. Como consequência, os participantes relataram autocontrole na alimentação e nas relações familiares e profissionais. Descritores: Essências Florais; Ensaio Clínico; Pesquisa Qualitativa; Ansiedade; Obesidade.

\section{RESUMEN}

Objetivo: Comprender la experiencia desde la perspectiva del participante de una investigación clínica, que tuvo como intervención la terapia floral para ansiedad de individuos con sobrepeso y obesidad. Método: estudio cualitativo, desarrollado por entrevista semiestructurada con 42 participantes de una investigación clínica y datos sometidos al análisis de contenido. Resultados: después del análisis, surgieron cinco categorías temáticas: Buscando alternativas naturales para auxiliar en el control de la ansiedad y la obesidad; Percibiendo los beneficios de la terapia floral en sí mismo y en personas de las relaciones familiares y profesionales; Reconociendo la terapia floral como fuente de tranquilidad y autoconocimiento; Percibiendo cambios en la calidad del sueño; Adquiriendo autocontrol y direccionamiento en las necesidades alimentarias y relacionales. Consideraciones finales: los participantes revelan la intención de buscar alternativas naturales para auxiliar el control de la ansiedad y la obesidad, apropiándose de terapias complementarias para fortalecer su salud. Como consecuencia, los participantes relataron autocontrol en la alimentación y en las relaciones familiares y profesionales.

Descriptores: Esencias Florales; Ensayo Clínico; Investigación Cualitativa; Ansiedad; Obesidad. 


\section{INTRODUCTION}

In 2013, the World Health Organization (WHO) developed the WHO Traditional Medicine Strategy: 2014-2023, which supports its Member States in the development of policies and implementation of action plans that strengthen the traditional medicine, prioritizing the health services and systems in the use of complementary practices ${ }^{(1)}$.

The complementary practices have been gradually incorporated in Brazil through the Unified Health System (SUS), as predicted by the National Policy on Integrative and Complementary Practices (PNPIC), an action that includes the complementary practices with quality, safety and effectiveness, considering the recognition of such practices by society ${ }^{(2)}$.

Regarding the inclusion of complementary practices in the SUS, we considered the flower therapy an integrative health complement, proceeding from flower essences, which are simple and natural, made from wild plants, flowers and trees of the field, and act by harmonizing the feelings, being compatible with any other form of treatment ${ }^{(3)}$. Edward Bach was the pioneer in using flower essences; throughout his work he showed how health and diseases are closely related with the way a person lives and the need to make changes in lifestyle ${ }^{(3)}$.

Obesity is a complex and multifactorial disease that is developed from the interaction of genetic, metabolic, social, behavioral, and cultural factors ${ }^{(4)}$. Worldwide, WHO estimates that in 2016, more than 1.9 billion adults were overweight and more than 600 million were obese ${ }^{(4)}$.

Anxiety is a frequent symptom among obese patients ${ }^{(5)}$ and includes sensations of fear, feelings of insecurity and apprehensive anticipation, thought content dominated by catastrophe or personal incompetence, increase of wakefulness or alert, feeling of respiratory constriction leading to hyperventilation and its consequences, muscle tension causing pain, tremor and restlessness and a variety of somatic discomforts resulting from hyperactivity of the autonomic nervous system ${ }^{(6)}$.

To treat these individuals, several strategies based on a multidisciplinary approach have been employed ${ }^{(7)}$. Considering the concern that the $\mathrm{WHO}$ demonstrates to health, with the inclusion of traditional medicine and complementary practices, we consider important the association of complementary practices to the treatment of anxiety associated with overweight and obesity.

As alternative to allopathic therapy to treat the anxious behavior of individuals with overweight or obesity and its unwanted side effects, the floral therapy is proposed as an integrative and complementary health strategy. Despite the literature having few clinical trials with floral therapy ${ }^{(8-10)}$, the experience of participants in this type of study was not found.

\section{OBJECTIVE}

To understand the experience from the perspective of the participant of a clinical research, which had as intervention the flower therapy for anxiety of individuals with overweight and obesity.

\section{METHOD}

\section{Ethical aspects}

To prepare this project, we followed strictly the provisions of Resolution no. 466/12, which stipulates regulatory guidelines and norms for research involving humans subjects ${ }^{(11)}$. This study was submitted to the Research Ethics Committee of the School of Medicine of Botucatu and approved in June 2016. All participants signed an the Informed Consent Form (ICF) aiming to clarity their agreement to the research, after full and detailed explanation on all stages of the research, including on the voice recording.

\section{Study type and data source}

This is a study with a qualitative approach and convenience sampling, in which individuals participated in a randomized, placebo-controlled and double-blind clinical trial. The aim of the research was to identify whether the treatment with floral therapy (Impatiens, Cherry Plum, White Chestnut, Chicory, Crab Apple and Pine) changed the degree of anxiety, sleep pattern and symptoms of binge-eating disorder of individuals with overweight or obesity (approved by the Brazilian Clinical Trials Registry under no. RBR-47kfxh).

There were included healthy subjects of both sexes, aged from 20 to 59 years, literate, overweight or obese according with the $\mathrm{WHO}$ criteria $^{(4)}\left(\mathrm{BMI} \geq 25 \mathrm{~kg} / \mathrm{m}^{2}\right)$ and with moderate or high anxiety according with the criteria of the State-Trait Anxiety Inventory ${ }^{(6)}$ (STAI with $\otimes 34$ score). There were excluded individuals who were taking medications for losing weight or controlling anxiety or depression, under psychological treatment and/or using other complementary therapies, in addition to pregnant women or with suspicion of pregnancy.

\section{Study scenario and data collection}

Data collection was conducted at a Clinical Research Unit from a Public Institution, part of the Brazilian National Clinical Research Network in Teaching Hospitals between June and November 2016, at the end of the individuals' participation in the clinical research. After such procedures, patients were invited to participate in a semi-structured interview designed to this study, with permission to record, to allow the faithful record of statements, enabling the transcript in full and subsequent analysis.

The interviews were conducted by the researcher of this project and two collaborators in a reserved environment in the unit, which ensured the privacy of researcher and respondent, so that there was no interruption during the interview. The collaborators were researchers of projects related to the main project, with knowledge of the objectives of this research and prepared to conduct the interview. The interviews had an average duration of 4 minutes and 11 seconds. To preserve the anonymity, participants were identified with numbering $(001,002,003$, etc.) corresponding to the order of the interviews conducted.

The guiding questions prepared for the interview were: What lead you to participate in a research with flower therapy? How was it to take the flower remedy this month? How did you feel during the month? What do you perceive as real benefit of having participated in a research with floral therapy? 


\section{Data analysis and theoretical-methodological framework}

For data organization and analysis, the content analysis according to Bardin was adopted as the methodological framework ${ }^{(12)}$. To analyze the data from interviews, according to the methodological framework, the three phases proposed were conducted: pre-analysis, analytical description and inferential interpretation ${ }^{(12)}$.

The pre-analysis organized the material and systematized the initial ideas into an analysis plan; the analytical description phase selected and chose the units of record, electing and codifying them, in a process named categorization that can be semantic/thematic, lexical, syntactical and expressive; the inferential interpretation clarified the data so they were meaningful and valid ${ }^{(12)}$.

In the categorization of this research, the lines were grouped into content of themes comparable for analysis, defined into semantic/thematic categories emerging from the data collected and interpreted so we could understand the patient's meaning and experience during a clinical research involving flower therapy.

The theoretical framework that supports this research in data analysis is the publications of Edward Bach, conceptual basis for the practice of flower therapy, especially the book $A$ terapia floral: escritos selecionados de Edward Bach (The flower therapy: selected writings of Edward Bach) ${ }^{(3)}$.

\section{RESULTS}

In the proposed period, all participants who completed the clinical research accepted to participate in this study. There were 42 individuals, being mostly females (41), with an average age of 40.1 years. Participants reported having white skin color, most were married (26), with an average of 1.3 children. As for education, 19 participants attended or had already completed higher education. In the professional context, 35 participants were employed and the monthly income of higher prevalence was $\mathrm{R} \$ 1,576.00$ to $\mathrm{R} \$ 3,151.99$.

In this study, we could understand the experience of participation in clinical research, being highlighted the following categories: seeking natural alternatives to aid in control of anxiety and obesity; perceiving the benefits of flower therapy in itself and in family and professional relationships; recognizing flower therapy as source of tranquility and self-knowledge; perceiving changes in sleep quality; acquiring self-control and guidance on food and relational needs.

\section{Category I: Seeking natural alternatives to aid in control of anxiety and obesity}

The lines illustrate the participant's concern with anxiety and obesity and the interest in non-pharmacological therapies for these symptoms.

I am very anxious, and I often take my anxiety out on food, and I didn't want to start using a drug, pill or controlled medicine for anxiety [...]. (002)

[...] the flowers could be helping in some... they wouldn't be diseases, like, messing with the emotional of the person and that would be benefiting on the outside. (009)

They are natural products... I talked about losing weight, decrease anxiety, and I'm anxious [...]. (013)
I suffer a lot from anxiety. When I heard from colleagues, from the research here, I thought: "it's worth a shot". That's what got me interested in coming, because I can't take too many types of medication, so I said: "who knows, right?" (042)

Category II: Perceiving the benefits of flower therapy in itself and in family and professional relationships

The demand for flower therapy was perceived after patients had already observed the improvement in themselves and in other people that used this therapy.

I've already took flower remedy once, a few times and I thought that the effect was cool, so I decided to participate again. (005)

It helped my nephew for a while, for being anxious, being an agitated child. And I discovered it and it really took effect. It took effect for a child of four years. That helped a lot in controlling anxiety. (011)

A niece of mine, she has a little daughter and now she's two, and she uses [...] that's why I'm interested too. (027)

I work with several people who told me that they take this treatment and that it is very good, that it helps a lot. It's been a while already, but I didn't want to go to a doctor. (030)

\section{Category III: Recognizing flower therapy as source of tran- quility and self-knowledge}

Through these speeches, participants showed that they were more attentive to their habits, felt more tranquil and calmer during the proposed treatment.

I think I got less annoyed, I didn't notice the premenstrual this month; I noticed that it was softened, and then, because of the amount of problems that have been happening, I think it was tranquil, I'd be more nervous. (007)

So, I had a lot of anxiety before. And this month I got, I got a little more tranquil. It decreased a little, the anxiety [...] I was always very agitated. (012)

[...] the only thing I was kinda, sorta... I don't know if I wasn't aware of the situation, but I noticed that I started to sweat with little efforts, with the tiny little things that I do, even when cold, I easily sweat. (016)

I felt I was tranquil... And I haven't been, like, very stressed. Although my job is very stressful. But, I thought I was a lot calmer than the other month. (021)

What I realized the most was staying calm, I was very calm in the days I took it [...] I've already taken other types of medications for weight loss and to control anxiety, and what I noticed was that this one left me calmer without any chemical composition, it is something natural, healthier, and the other medications got me totally out of control. (031)

\section{Category IV: Perceiving changes in sleep quality}

The participants perceived their own ability of dealing with past failures, while blocking the clarity of their own ability in dealing with their harmonious balance, relating changes in sleep quality to other factors than the use of flower remedy. 
I thought it helped me a lot, the sleep, I slept much better [...] I thought it did well for me, especially on the part of sleeping. (002)

I slept, I slept better, I don't know if this is it because I get up several times at night, I have pain, I always get IV shots, understand? This month I had two renal crises, passed two stones, so I have constant pain and I even slept better, so it may be that [the flower remedy]. (008)

In the first 15 days the only difference is that it really messed with my sleep, I don't know if it has a lot to do, but I was waking up in the middle of the night, earlier even sometimes, at 4:00 in the morning I was awake and I couldn't sleep. I dreamt a lot about things kept there in at the bottom of my heart, stuff I didn't even want to remember and ended up dreaming, I had nightmare I think. Then the rest was normal [...], due to the fact that it really messed with my sleep, which is something I have no problem with [...], to keep dreaming, having some nightmares at night was bad, [...] it seems to dredge up some little things kept there in the past, at the bottom of the heart [...], it seems that we are gonna do some cleanup and clean things that are there in the corner for only then staying calm, that's what happened to me. (023)

During the day, at bedtime, I slept more easily, because I had a little difficulty to lie down and until the sleep come, then I started feeling much better [...], I'm feeling good to sleep, but it must be because of the winter, but anyway. At sleep, especially at night to sleep I felt better. If it made me ill I could associated it to the medicine, but only at bedtime I felt a certain difference. (024)

\section{Category V: Acquiring self-control and guidance on food and relational needs}

In the lines described, we observed encouragement and self-control, making individuals free of limiting influences, facing their own ability in perceiving their irrational attitudes, as in feeding and difference in physical and mental exhaustion, noticing better performance at work.

I think, for me, it was about figuring out how we fit into bad habits of eating, sleeping, everything. (007)

I felt calmer, because the attitude of my children let me very nervous [...] I lose patience very easily with them [...] I was very quieter, very less anxious. With the children, anything and I yelled. I didn't yell at them. They kept doing, doing, doing... instead of blowing up, it took me much longer. I felt much more "patientous" really. (017)

In relation to food, I don't know if it's because of the flower remedy or because of my nervous system, I thought it became much more stable [...]. I acted differently towards my son, who has health problems. I managed to have a good control, now if it was because of the flower medicine, I don't know. I had a good control. (032)

Because besides making me calmer, it encouraged more my dietary re-education [...] to sleep well, talk better with people without being stressed, these kinds of things like that [...]. There where I work to deal with people, sometimes the same question, not because it's their fault [patients], but it was making me really annoyed. So sometimes you answer... and not now, you're calmer, it can be the $50^{\text {th }}$ patient, but it seems like that's the first one coming. (034)
I could notice the moments I ate without being hungry, I didn't have this control before. I used to eat for no reason, but not anymore, now I see that I eat without being hungry. As for will, not out of necessity. I could perceive myself, I couldn't control it that much, but I could see I'm eating without necessity [...] I felt more willingly and started to try. I think that, because of this, I began to pay more attention to my actions and could really discriminate when I eat being hungry or not. So I think that, anyway, it alerted me for suddenly becoming more aware of my habits. (035)

I perceived the activities in my job, because I am a hyper-agitated person, and I got even more! I wouldn't be that tense anymore, I know I was being productive at my job. I'd work, work... Oh my! Is it 11:00 already? Seems like I'm faster! That's how I felt. (038)

\section{DISCUSSION}

The search for natural treatment alternatives shows the interest for complete healing, since it essentially comes from inside of us, from our soul. The harmony of our personality will be achieved using methods that are better and more familiar to the art of healing. To eliminate any failure in our nature, nothing better than nature's own products that will act causing the opposite virtue, which will eliminate the fault ${ }^{(3)}$.

In the lines, we observed the participants' desire in using what Dr. Bach called "medicine and nursing of the future", when the therapists will provide greater care to the development, since at the slightest symptom of illness, we will spend a few hours in harmony with our higher self and the disease will be repelled ${ }^{(3)}$.

Study participants showed to be interested in the knowledge of supraphysical truths which include methods to overcome illnesses through the spirit and the faith, seeking ancient teachings and Eastern wisdom. Almost 100 years after the writings of Dr. Bach, it is noticed that people begin to consider the emotional processes as important sources of everyday balance or imbalance ${ }^{(3)}$.

The reports of faith and optimism are in agreement with the writings of Dr. Bach, when he states that the flower remedies will bring relief, health and joy, necessary to achieve full health, because nothing from nature can hurt us when we are happy and live in harmony ${ }^{(3)}$.

A study conducted with children and adolescents with cancer showed the satisfaction that users of flower therapy feel and that $68 \%$ of children and $55 \%$ of adolescents were confident that the alternative and complementary therapy had beneficial effects. In this same study, $97 \%$ of parents reported that they would recommend the alternative and complementary therapy to other persons ${ }^{(13)}$.

Thus, when observing the improvement on other people, we have the opportunity of developing our individuality, achieving the freedom to search in the world the knowledge and experience necessary for our evolution ${ }^{(3)}$.

The truth is part of us, and can be perceived in a flash. It does not need to be analyzed or discussed ${ }^{(3)}$. In this regard, participants expressed the perception of this reality because they payed attention to their habits and their changes; they could perceive when something was happening different from the normal and they acted by taking the therapy.

By perceiving the mistake that causes a change, we will strive to correct it, relieving the suffering and illness of the soul. This correction will leave us free to follow the evolution of a life of joy, peace, love and health ${ }^{(3)}$. 
Flower essences reorganize the emotional patterns, making the person to return to a harmonious balance level ${ }^{(8)}$. A study states that the stress and anxiety often produce or exacerbate physical symptoms, and represent $70 \%$ to $90 \%$ of the healthcare appointments at a primary level ${ }^{(14)}$.

Some studies show good results of flower therapy as, for example, a research with flower therapy and placebo, in which both groups had descendant trends on the indicators of anxiety level during the test ${ }^{(15)}$. In another research, the intervention with flower therapy also reduced the anxiety in individuals who underwent this treatment ${ }^{(8)}$.

Some flower remedies are related to poor sleep quality, others are intended for excess patterns of thoughts, concerns, fear and exhaustion and nonharmonic energetic patterns, such as lack of mind anchoring. The flower will strengthen the quality, and the personality will eliminate the fault, providing a better balance of feelings ${ }^{(3)}$. The sleep plays a key role in maintaining the emotional well-being, the imbalance in any one of those parties will affect the other ${ }^{(16)}$.

In a study on pain control with flower therapy, participants described feeling "not like myself" before treatment, and after, feeling "more normal", or "more like myself"(17). Participants opened up to the researcher about deep emotional issues, stating having felt able to resolve during treatment, described by participants as "relief" and "cleaning", providing a feeling of "calmness" and "relaxation"(17).

We observed the same terms in the interviews conducted, as "things kept at the bottom of the heart", "do some cleanup", "clean things", when the participant reports that taking flower remedy influenced a lot in their sleep, making them dream things that were forgotten in the memory and that caused some suffering to feelings, because the flower remedy helped rescuing these pains and made the participant face this forgotten suffering for later experiencing a feeling of calmness.

This study showed that individuals who accept well the flower therapy are spiritually receptive to a strong desire of well-being, regardless of any clinical improvement, they believe that they got even better ${ }^{(17)}$. We found the same result, even not admitting that the improvement resulted from the therapy, the lines demonstrate the participants' receptivity to the flower therapy because they perceive improvements after the beginning of treatment.

In addition to the improvement of sleep, other studies show the Bach flower remedies effective for pain relief ${ }^{(11)}$ and relief on the symptoms of menopause, as anxiety, mood swings and insomnia ${ }^{(18)}$.

People have no clear sources of their behavior. They see and hear what is more convenient, and what happens to them is better understood subjectively in their perceptions and feelings. To not perceive a sign does not mean its nonexistence, but rather the person's incomprehension. Sensory stimulation, organization of the forces of nervous system and the replacement of experiences are required to find the answer ${ }^{(19)}$.
The disease is how our soul points our failures to prevent us from making bigger mistakes ${ }^{(3)}$. Participants showed us the same reaction described by Dr. Bach, since they describe the perception of inappropriate attitudes both in feeding, in which they perceived using food to escape from feelings, and in family and professional relationships, with a better manner to relate to their children, colleagues from work, customers at work, showing more balanced attitudes, for example.

For energetic interventions, such as the flower remedies, there is the concern of obtaining the greatest efficiency as possible on a situation or condition involving, most of the times, more than a feeling ${ }^{(16)}$.

\section{Study limitations}

The reduced number of studies on flower therapy found in the literature made difficult the discussion of the results obtained.

Contributions to the fields of nursing, health, or public policy

Given these results, this study contributes to a better perception of the participants' perspective in a double-blind clinical study using flower therapy and placebo. Knowing their perspectives, the acceptance of flower therapy by health professionals can be facilitated, because the low adherence to these practices can be due to the non-knowledge or few reports of results with its use.

\section{FINAL CONSIDERATIONS}

The results of this study show us the participants' intention of seeking natural alternatives to aid the control of anxiety and obesity, increasingly appropriating complementary therapies to strengthen their health. And as a consequence of the participation, our results show that these participants could achieve self-control during their feeding and in relationships because they could pay attention to their inappropriate behaviors during feeding in addition to perceiving their irrational attitudes during the interaction with family and work relationships.

This search is consolidated mainly by the benefit that the participants already observed during the use of complementary therapy by itself or by individuals of their circle of relationships, showing the existing compassion in human relationships.

Participants identified the flower therapy as motivation for tranquility and self-knowledge according to their reports, since they began to better understand the little changes that happen to the body, which could eventually cause some physical illness.

The balance of anxious emotions and symptoms reported shows that participants could successfully face past situations that caused suffering, showing the effectiveness of flower therapy in this context.

\section{REFERENCES}

1. World Health Organization-WHO. Traditional Medicine Strategy 2014-2023[Internet]. Genebra, Suíça: WHO; 2013[cited 2018 Jan 08]. Available from: http://apps.who.int/medicinedocs/documents/s21201en/s21201en.pdf

2. Brasil. Ministério da Saúde. Secretaria de Atenção à Saúde. Departamento de Atenção Básica. Política nacional de práticas integrativas e complementares no SUS: atitude de ampliação de acesso[Internet]. 2. ed. Brasília, DF; 2015[cited 2018 Jan 08]. Available from: 
http://bvsms.saude.gov.br/bvs/publicacoes/politica_nacional_praticas_integrativas_complementares_2ed.pdf

3. Venancio D, (Org.). A terapia floral: escritos selecionados de Edward Bach. 11. ed. São Paulo: Ground; 2014

4. World Health Organization-WHO. Media Centre. Fact sheet $n^{\circ} 311$ [Internet]. Genebra: WHO; $2016[$ cited 2018 Jan 08]. Obesity and overweight[7 p.]. Available from: http://www.who.int/mediacentre/factsheets/fs311/en/.

5. Gariepy G, Nitka D, Schmitz N. The association between obesity and anxiety disorders in the population: a systematic review and meta-analysis. Int J Obes[Internet]. 2010[cited 2018 Jan 08];34:407-19. Available from: https://www.nature.com/articles/ ijo2009252.pdf

6. Fioravanti ACM. Psychometric Proprieties of the State-Trait Anxiety Inventory-STAI[Dissertação] [Internet]. Rio de Janeiro: Pontifícia Universidade Católica; 2006[cited 2018 Jan 08]. Available from: https://www.maxwell.vrac.puc-rio.br/Busca etds.php?strSecao = resultado\&nrSeq=9650@2

7. Aronne LJ. Current pharmacological treatments for obesity. In: Fairbuirn \& Brownell (Eds). Eating disorders and obesity. 2. ed. Nova lorque: Guilford Press, 2003. p. 551-6.

8. Salles LF, Silva MJP. Effect of flower essences in anxious individuals. Acta Paul Enferm[Internet]. 2012[cited 2018 Jan 08];25(2):23842. Available from: http://www.scielo.br/pdf/ape/v25n2/en_a13v25n2.pdf

9. Maduro IPNN, Tavares ARDS, Horstmann H, Couceiro KDN. SUN-LB019: Placebo-Controlled study for evaluation of commercially available formula "Bach Flower for Weight Loss" and binge eating in obese patients. Clin Nutr[Internet]. 2015 [cited 2018 Jan 08];34:S242. Available from: http://www.clinicalnutritionjournal.com/article/S0261-5614(15)30740-8/pdf

10. Rivas-Suárez SR, Águila-Vázquez J, Suárez-Rodríguez B, Vázquez-León L, Casanova-Giral M, Morales-Morales R, et al. Exploring the effectiveness of external use of Bach flower remedies on carpal tunnel syndrome: a pilot study. J Evid Based Complement Altern Med[Internet]. 2017[cited 2018 Jan 08];22(1):18-24. Available from: http://journals.sagepub.com/doi/pdf/10.1177/2156587215610705

11. Brasil. Conselho Nacional de Saúde. Resolução n. 466, de 12 de dezembro de 2012[Internet]. Brasília, DF; 2012 [cited 2018 Jan 08]. Available from: http://bvsms.saude.gov.br/bvs/saudelegis/cns/2013/res0466_12_12_2012.html

12. Bardin, L. Análise de conteúdo. 11. Ed. São Paulo: Edições 70; 2011.

13. Gottschling S, Meyer S, Längler A, Scharifi G, Ebinger F, Gronwald B. Differences in use of complementary and alternative medicine between children and adolescents with cancer in Germany: a population based survey. Pediatr Blood Cancer[Internet]. 2014[cited 2018 Jan 08];61(3):488-92. Available from: http://onlinelibrary.wiley.com/doi/10.1002/pbc.24769/epdf

14. Halberstein RA, Sirkin A, Ojeda-Vaz MM. When less is better: a comparison of Bach flower Remedies and homeopathy. Ann Epidemiol[Internet]. 2010[cited 2018 Jan 08];20(4):298-307. Available from: https://linkinghub.elsevier.com/retrieve/pii/ S1047-2797(09)00362-7

15. Halberstein R, DeSantis L, Sirkin A, Padron-Fajardo V, Ojeda-Vaz M. Healing with Bach flower essences: testing a complementary therapy. Complement Health Pract Rev[Internet]. 2007[cited 2018 Jan 08];12:3-10. Available from: http://journals.sagepub.com/ doi/pdf/10.1177/1533210107300705

16. Nosow SKC, Ceolim MF. Selection of Bach flowers for improving sleep quality. Rev Enferm UFPE [Internet]. 2016 [cited 2018 Jan 08];10(Suppl-4):3662-8. Available from: https://periodicos.ufpe.br/revistas/revistaenfermagem/article/view/11141/12642

17. Howard J. Do Bach flower remedies have a role to play in pain control? a critical analysis investigating therapeutic value beyond the placebo effect, and the potential of Bach flower remedies as a psychological method of pain relief. Complement Ther Clin Pract[Internet]. 2007[cited 2018 Jan 08];13(3):174-83. Available from: https://linkinghub.elsevier.com/retrieve/pii/S1744-3881(07)00005-9

18. Siegler M, Frange C, Andersen ML, Tufik S, Hachul H. Effects of Bach flower remedies on menopausal symptoms and sleep pattern: a case report. Altern Ther Health Med[Internet]. 2017[cited 2018 Jan 08];23(2):44-8. Available from: https://www.ncbi.nlm.nih. gov/pubmed/28323628

19. Silva MJP. Comunicação tem remédio: a comunicação nas relações interpessoais em saúde. 10 ed. São Paulo: Edições Loyola; 2015. 